\title{
IbM Pengelola Paud Al Amin Untuk Peningkatan Science Instructional Quality Anak Usia Dini dan Parenting Skill Orang Tua Murid
}

\author{
Mujtahidin \\ Program Studi Pendidikan Guru Sekolah Dasar Fakultas Ilmu Pendidikan \\ Universitas Trunojoyo Madura \\ E-mail : mujtahidin@trunojoyo.ac.id
}

http://dx.doi.org/10.21107/pgd.v4i2.4927

\begin{abstract}
Abstrak
Tujuan program IbM ini adalah mensinergikan antara pola pendidikan di sekolah yang dilakukan guru dan pola asuh orang tua dalam pendidikan di dalam keluarga untuk anak usia dini. IbM ini dilakukan untuk guru-guru dan orang tua murid di PAUD Al Amin, Kabupaten Pamekasan-Madura. Oleh karena itu, program IbM ini memberikan bekal bagi guru dan orang tua dalam menjalankan proses pengasuhan dan pendidikan anak dengan mudah dan tepat. Program IbM ini berisi paket pelatihan penyusunan rencana pelaksanaan pembelajaran harian (RPPH) untuk meningkatkan science instructional quality, pengembangan media pembelajaran sains untuk guru, dan pelatihan parenting skill untuk orang tua murid. Capaian hasil kegiatan IbM dapat dilihat dari perubahan mindset guru dan orang tua sedikit demi sedikit dalam pola asuh anak. Guru menjadi terampil dalam mengembangkan RPPH untuk pembelajaran anak usia dini, guru terampil dalam mengembangkan media yang sesuai dengan tahapan perkembangan anak. Guru dan orang tua memperoleh pengetahuan tentang persiapan ruang mental dalam memfasilitasi perkembangan mental positif anak, prinsip-prinsip dasar dalam membentuk sikap dan perilaku anak, melatih secara sehat dan efektif dalam menjalani pengasuhan anak, motivasi gairah belajar orang tua, serta membantu orang tua dalam membina hubungan lebih berkualitas dengan anak untuk mendukung terciptanya keluarga berkualitas yang menyenangkan dan tentram.
\end{abstract}

Kata Kunci : anak usia dini, science instructional quality, dan parenting skill

\section{PENDAHULUAN}

Proses pembelajaran yang berlangsung di PAUD Al Amin kurang memberikan pengetahuan dan keterampilan sains kepada siswa. Kurangnya pengenalan konsep sains di PAUD Al Amin disebabkan guru kesulitan dalam memilih model, strategi pembelajaran sains, sistem penilaian dan menyusun skenario pembelajaran sains. Kurangnya pengalaman guru dalam mengikuti pelatihan-pelatihan dan kurangnya sinergi peruruan tinggi untuk perbaikan pembalajaran PAUD mengambil peran penting dalam terciptanya situasi ini. Padahal pengenalan pemahaman sains sangat penting diberikan bagi siswa PAUD karena dapat melatih siswa dalam menggunakan lima inderanya untuk mengidentifikasi dan mengeksplorasi berbagai gejala dan peristiwa. Dengan demikian setiap anak dapat memetik manfaat dari berbagai peristiwa sains dan menganalisisnya sehingga membentuk anak untuk berlogika dan berpikir sehat serta mampu bekerja layaknya seorang ilmuwan.

Dalam pembelajaran sains PAUD diperlukan keahlian khusus dalam membelajarkannya. Dalam pembelajaran sains guru dituntut untuk memberikan bekal basic science skill pada murid
(George, 2012). Sehingga kegiatan pengabdian ini menitikberatkan dalam menciptakan guru PAUD sebagai pendidik anak yang mampu mengemas pembelajaran sains PAUD menjadi menyenangkan dan perlu dilakukan upaya pemberdayaan guru dalam meningkatkan kreatifitas dalam membuat dan mengembangkan media pembelajaran sains PAUD.

Selain permasalahan proses pembelajaran sains, permasalahan lain yang ada yaitu, kurangnya sarana dan prasarana berupa bukubuku sains PAUD dan media pembelajaran yang mendukung proses pembelajaran sains. Sarana yang terbatas terutama media dan buku sains menyebabkan guru kurang kreatif dan inovatif dalam membelajarkan sains untuk anak usia dini (AUD).

Program IbM ini juga dilakukan pada Paguyuban Orang Tua Murid dan Guru (POMG). Program peningkatan kompetensi guru juga harus diikuti oleh pemahaman orag tua dalam mendidik anak di rumah. Orang tua dan sekolah adalah mitra. Untuk memastikan perkembangan anak yang sehat, sekolah membutuhkan dukungan dan bantuan orang tua. Oleh karena itu, pihak keluarga dan sekolah harus menjalin hubungan yang erat untuk memahami kinerja 
anaknya di sekolah, yang pada gilirannya akan memperbaiki koordinasi antara kedua pihak. Partisipasi aktif orang tua dapat meningkatkan sinergi kerja sama keluarga dan sekolah (Biro Pendidikan, 2012).

Dalam dasawarsa terakhir, pergeseran nilainilai dalam masyarakat mulai sering terjadi. Halhal yang dulunya dianggap tabu, saat ini menjadi hal biasa. Kasus korupsi, fenomena penampilan para remaja dengan pakaian ketat dan mininya, gaya pacaran yang berlebihan, sampai tragedi hamil di luar nikah (Sharry, 2002; Wiyono, 2008). Banyak contoh kasus yang melibatkan kekerasan terhadap anak, seperti kasus pembunuhan terhadap anak kandung yang dimulai dari kasus kekhawatiran orang tua dalam memenuhi kebutuhan anak.

Inilah pentingnya peran orang tua dalam menjadikan anak berkepribadian yang baik atau tidak, berakhlak atau tidak, berbudi pekerti atau tidak, berkarakter mulia atau tidak, taat beragama atau tidak, mampu berhubungan baik dengan orang lain atau tidak, mampu mengendalikan dirinya atau tidak, dan masih banyak lagi hal lainnya. Jika anak tumbuh dalam keluarga yang baik dan orang tuanya baik, kemungkinan besar anak akan tumbuh dengan baik. Jika anak tumbuh di lingkungan yang tidak baik, kemungkinan besar anak akan mengikuti lingkungannya.

Oleh karena itu, untuk mengatasi minimnya pengetahuan tentang model-model pembelajaran sains PAUD, penyusunan RPPH, pengembangan media pembelajaran sains PAUD dalam program IbM ini dilakukan dengan memberikan pelatihan pengemasan pembelajaran sains yang kreatif, inovatif dengan konsep belajar sambil bermain. Melalui kegiatan ini, diharapkan pengetahuan tentang model pembelajarn sains PAUD dapat meningkat serta kemampuan pendidik PAUD dalam menyusun RPPH berbasis keterampilan proses sains, pelatihan pembuatan dan pengembangan media pembelajaran sains sederhana untuk PAUD, serta pegadaan buku sains dan media pembelajaran sains PAUD.

Selain kegiatan pelatihan terkait peningkatan kompetensi guru, program IbM ini juga melakukan pelatihan Parenting skill yang masih belum di kuasai oleh orang tua murid PAUD Al Amin sehingga orang tua kurang memperhatikan pertumbuhan dan perkembangan anak. Orang tua sepenuhnya pasrah pada pendidikan formal. Oleh karena itu, agar ada sinergi antara pendidikan di sekolah dan di rumah, maka IbM ini juga memberikan bekal parenting kepada orang tua murid.

Program IbM ini juga memberikan bekal bagi guru dan orang tua dalam menjalankan proses pengasuhan dan pendidikan anak dengan mudah dan tepat, orang tua juga akan mendapatkan pengetahuan tentang persiapan ruang mental untuk memfasilitasi perkembangan mental positif anak dalam keluarga. Selain hal tersebut, orang tua akan mendapatkan prinsip pola mendasar sikap prilaku anak memahami pola reaksi, kualitas bagi perkembangan anak, melatih secara sehat dan efektif dalam menjalani pengasuhan anak, motivasi gairah belajar orang tua, serta membantu orang tua membina hubungan lebih berkualitas dengan anak untuk mendukung terciptanya keluarga berkualitas yang menyenangkan dan tentram.

\section{METODE}

Metode pendekatan yang dilakukan untuk mengatasi permasalahan mitra adalah pelatihan transfer iptek dan pendampingan. Pelatihan dan pendampingan dilakukan untuk memberikan pengetahuan tentang model-model pembelajaran sains PAUD, mengemas pembelajaran sains PAUD yang kreatif dan inovatif secara menyenangkan dalam konsep bermain sambil belajar, pelatihan pembuatan dan pengembangan media pembelajaran sains PAUD. IbM ini juga memberikan bekal bagi para orang tua siswa PAUD berupa pelatihan parenting skill sehingga orang tua mempunyai bekal dalam pola pengasuhan anak yang mudah dan tepat dan adanya sinergi antara sekolah orang tua.

Langkah-langkah yang dilakukan untuk mengatasi permasalahan yang dihadapi oleh mitra adalah: (1) pelatihan dan pendampingan pengemasan pembelajaran sains yang kreatif dan inovatif, (2) melakukan pelatihan parenting skill, (3) pelatihan dan pendampingan pembuatan media pembelajaran sains PAUD, dan (4) menyediakan sarana dan prasarana pembelajaran sains.

\section{HASIL DAN PEMBAHASAN}

Pelaksanaan kegiatan IbM telah dilakukan secara bertahap sesuai proposal yang meliputi: Pelatihan Penyusunan Rencana Pelaksanaan Pembelajaran Harian (RPPH); Evaluasi proses belajar mengajar; Melakukan pelatihan dan pendampingan tentang pengemasan pembelajaran sains yang kreatif dan inovatif; Menyusun SK/KD, Memilih pendekatan, model, dan metode pembelajaran yang tepat dan sesuai dengan usia anak, membuat RPPH. Melakukan 
pelatihan media pembelajaran sains anak usia dini (terarium): menyiapkan bahan, memilih tanaman hias, penyusunan komponen media, penanaman, penamaan dan pemeliharaan. Melakukan pelatihan parenting skill: Evaluasi proses belajar mengajar dan pola asuh orang tua, Pelatihan parenting skill bagi guru dan orang tua, Pendampingan. Pengadaan sarana prasaraan berupa buku sains PAUD dan media pemebalajarn sains PAUD.

Selama pelatihan dan sesudah pelatihan dilakukan Monitoring dan Evaluasi per tahapan. Semua tahap kegiatan yang direncanakan belum dapat dilaksanakan secara keseluruhan, serta ada beberapa perubahan jadwal.

\section{Pelatihan Model Pembelajaran Sains Bagi Anak Usia Dini (AUD)}

Hasil pelatihan model pembelajaran sains bagi anak usia dini telah berhasil meningkatkan pengetahuan guru dalam memahami model pembelajaran sains untuk diterapkan di PAUD. Pelatihan ini bertujuan memberikan pemahaman kepada guru PAUD peserta pelatihan agar memiliki wawasan tentang model pembelajaran sains yang bisa diterapkan pada anak usia dini. Dengan wawasan yang bertambah tentang model pembelajaran sains tersebut maka nantinya guru PAUD dapat menciptakan pembelajaran yang efektif, efisien dan menarik bagi siswa anak usia dini (Jacqueline, 2003). Pengetahuan tentang model pembelajaran ini juga dapat membantu guru untuk menyajikan suasana pembelajaran yang bervariasi sehingga dapat mencegah kebosanan pada siswa anak usia dini. Dalam penerapan pembelajaran di PAUD terdapat kendala yang diungkapkan oleh guru-guru peserta pelatihan. Kendala di lapangan saat melakukan pembelajaran anak usia dini antara lain: (1) guru kurang kurang kreatif, (2) anak kurang semangat, (3) anak tidak fokus dan sibuk main sendiri, (4) alat peraga pembelajaran kurang memadai, dan (5) lingkungan kelas kurang mendukung.

Berdasarkan beberapa kendala yang dipaparkan di atas maka solusi yang dapat dilakukan untuk mengatasi kendala tersebut antara lain: (1) diadakan pelatihan model pembelajaran sains bagi anak usia dini untuk memperkaya teknik guru dalam menciptakan pembelajaran yang efektif, efisien, dan menarik, (2) disumbangkannya beberapa alat peraga dan media pembelajaran untuk mempermudah pembelajaran dan meningkatkan semangat siswa dalam belajar sains.

\section{Pelatihan Penyusunan Rencana Pelaksanaan Pembelajaran Harian (RPPH)}

Pelatihan penyusunan RPPH berbasis sains skills process bagi anak usia dini. Pelatihan dilaksanakan di ruang kelas PAUD Al Amin, pelatihan ini berlangsung 1 hari dan disambut dengan antusias oleh para guru PAUD Al Amin.

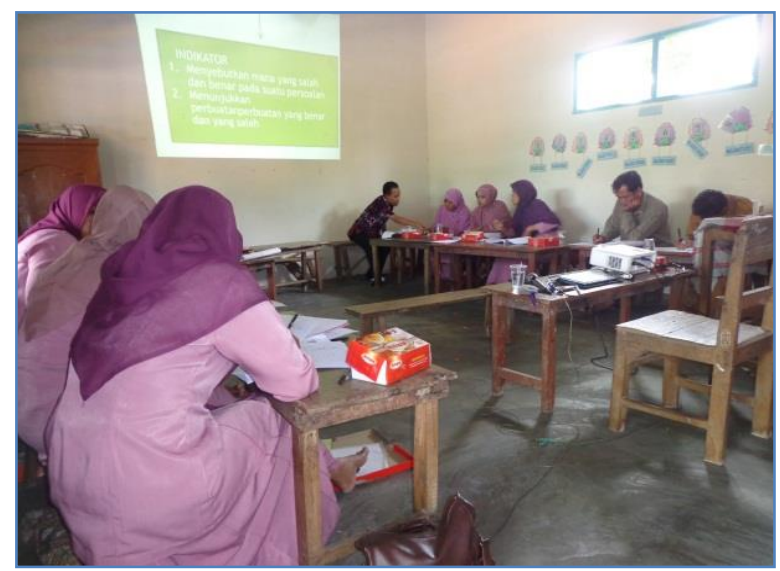

Gambar 1. Pendampingan Penyusunan RPPH

Dengan adanya RPPH maka pembelajaran tidak akan melenceng dari rencana yang telah disusun. Rencana kegiatan Harian terdiri dari; Kegiatan awal, kegiatan inti, istirahat dan kegiatan akhir. Adapun langkah-langkah dalam penyusunan RPPH adalah: (1) memilih dan menata kegiatan ke dalam RPPH, (2) memilih kegiatan yang dipilih ke dalam kegiatan awa, kegiatan inti, dan kegiatan akhir. Pada kegiatan inti, kegiatan pembelajaran dibagi dalam kelompok sesuai program yang direncanakan dan terdapat satu kelompok yang ditunggu; (3) memilih metode yang sesuai dengan kegiatan yang dipilih, (4) memilih alat/sumber belajar yang dpat menunjang kegiatan pembelajaran yang akan dilakukan, dan (5) memilih dan menyusun alat penilaian yang dapat mengukur ketercapaian hasil belajar.

Peserta yang hadir antusias dengan materi yang diberikan sebab kegiatan ini merupakan yang pertama kali dilakukan di PAUD Al Amin. Pada sesi diskusi, banyak pertanyaan yang muncul terkait dengan bagaimana menyusun RPPH berbasis keterampilan proses sains dan menjadikan anak lebih aktif dalam pembelajaran. Harapan tim pelaksana IbM, kemampuan guru dalam memilih model pembelajaran, metode dan sumber belajar/alat yang digunakan dapat sesuai dengan rencana kerja yang akan dilaksanakan pada saat proses pembelajaran. Karena sebelumnya para guru sudah mempunyai pengetahuan terkait model pembelajaran sains anak usia dini. Beberapa pertanyaan yang 
muncul adalah bagaimana tentang pemilihan model pembelajaran dan metode yang tepat dalam pembelajaran. Oleh karena itu, pada sesi pendampingan, guru dilatih menyusun sendiri RPPH yang kemudian didiskusikan dengan pemateri dan masukan dari teman-teman guru yang lain. Hasil pelatihan dan pendampingan ini telah berhasil meningkatkan pengetahuan guru dalam menyusun RPPH berbasis keterampilan proses sains.

\section{Pelatihan Parenting Skill}

Pelatihan parenting skill diberikan untuk memberikan bekal pola asuh yang baik bagi guru PAUD dan POMG agar ada sinergi pola asuh antara sekolah dan di rumah. Pelatihan dilakukan selama 1 hari dengan pemateri salah satu dosen PG-PAUD UTM dengan bidang keahlian psikologi perkembangan.

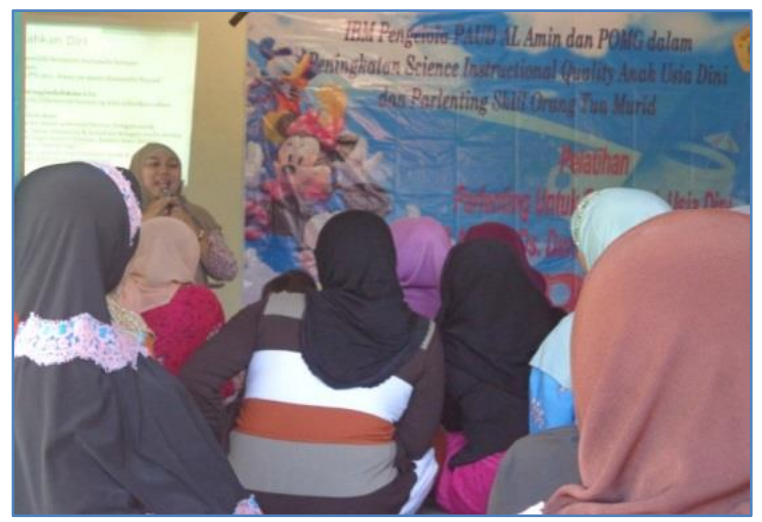

Gambar 2. Pelatihan Parenting Skill

Pelatihan dilaksanakan di mushalla PAUD Al Amin dikarenakan terbatasnya ruang kelas. Peserta pelatihan sangat antusias dalam mengikuti pelatihan parenting skill. Hal ini karena pelatihan ini merupakan pelatihan yang pertama kali dilaksanakan di PAUD Al Amin. Selama pemaparan materi, para orang tua banyak yang merasa telah mengalami kesalahan dalam mendidik anak, bahkan beberapa guru juga mengalami hal sama. Kemampuan parenting merupakan kemampuan mengasuh dengan memberikan perhatian, waktu dan dukungan yg berkualitas untuk memenuhi kebutuhan fisik, mental, dan sosial anak-anak disesuaikan aplikasi kegiatan sehari-hari (Novan, 2013). Terdapat 10 kebiasaan orang tua dalam mendidik anak yang ditampilkan yaitu: (1) menakuti anak, (2) sering berbohong kecil, (3) banyak mengancam, (4) campur tangan (kakek, nenek), (5) mudah menyerah dan pasrah, (6) merendahkan diri, (7) bicara tidak tepat sasaran, (8) mengungkit masa lalu, (9) menghukum saat marah, dan (10) mengajari membalas (Navis, 2013). Dari ke sepuluh poin tersebut di atas, hamper semua orang tua melakukan hal tersebut. Dalam pelatihan ini, diberikan bagaimana tips dalam mendidik anak dalam kehidupan sehari-hari. Setelah pelatihan, dilakukan simulasi dengan anak PAUD Al Amin. Hal ini agar ada aplikasi langsung dalam mendidik anak. Beberapa guru dan orang tua akhirnya banyak yang curhat terkait permasalahan anak dan siswa mereka. Pada intinya, perilaku anak terbentuk berdasarkan: (1) siapa yang lebih dulu mengajarkan, (2) siapa yang lebih dia percaya, (3) siapa yang menyampaikan lebih menyenangkan, dan (4) siapa yang lebih sering menemaninya.

\section{Pelatihan Media Pembelajaran}

Pelatihan dan pendampingan media pembelajaran sains PAUD. Pelatihan ini diikuti oleh semua guru PAUD Al Amin. Hampir semua guru PAUD Al Amin kurang memahami tentang media pembelajaran sains PAUD. Hal ini terlihat dari antusiasme pertanyaan yang diajukan oleh peserta. Sebelum diadakan pelatihan, sangat jarang guru PAUD Al Amin menggunakan media pembelajaran untuk membelajarkan sains. Hal ini dikarenakan terbatasnya buku-buku pendukung tentang sains PAUD dan media pembelajaran sains.

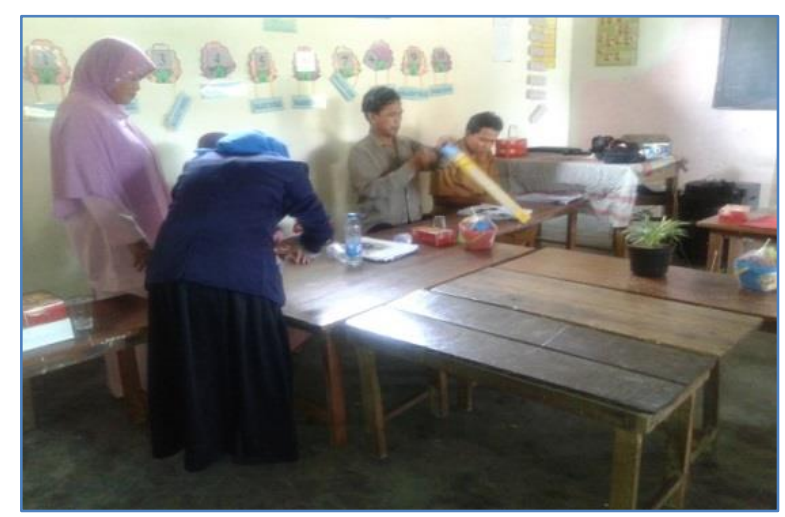

Gambar 3. Pendampingan Pembuatan Media Pembelajaran Sains PAUD

Pelatihan menekankan pada bagaimana ciriciri media yang baik dan pemilihan media yang sesuai dengan pertumbuhan dan perkembangan anak (Richard, 2007). Pada guru PAUD Al Amin juga dibekali dengan pembuatan media terarium. Dalam pelatihan ini, para guru terlihat sangat antusias dalam mengikuti pelatihan. Karena dalam pelatihan ini para guru langsung mengambil media kemudian mengidentifikasi apakah media sesuai dengan perkembangan anak 
atau belum. Banyak pertanyaan yang diajukan oleh para peserta karena di PAUD Al Amin sangat kekurangan media pembelajaran terutama untuk membelajarkan sains. Selanjutnya dilakukan pendampingan pembuatan media pembelajaran. Pendampingan dilakukan agar guru betul-betul mampu dalam mengembangkan dan memilih media agar betulbetul sesuai dengan tahapan perkembangan anak. Harapan tim IbM, media yang dikembangkan bisa sekaligus untuk digunakan dalam proses pembelajaran.

\section{Pengadaan Buku dan Media Pembejalaran Sains PAUD}

Usia PAUD merupakan usia emas (golden age), pada usia ini merupakan peletakan dasar tentang konsep dan perilaku anak. Oleh karena itu, pembelajaran di PAUD harus benar-benar dijamin kualitasnya untuk membentuk karakter dan konsep anak tentang sains. Berdasarkan permasalahan yang muncul, salah satunya adalah minimnya sumber belajar (buku dan media pembelajaran sains PAUD). Oleh karena itu, dalam kegiatan IbM ini juga terdapa program pengadaan media pembelajaran dan buku-buku sains anak usia dini.

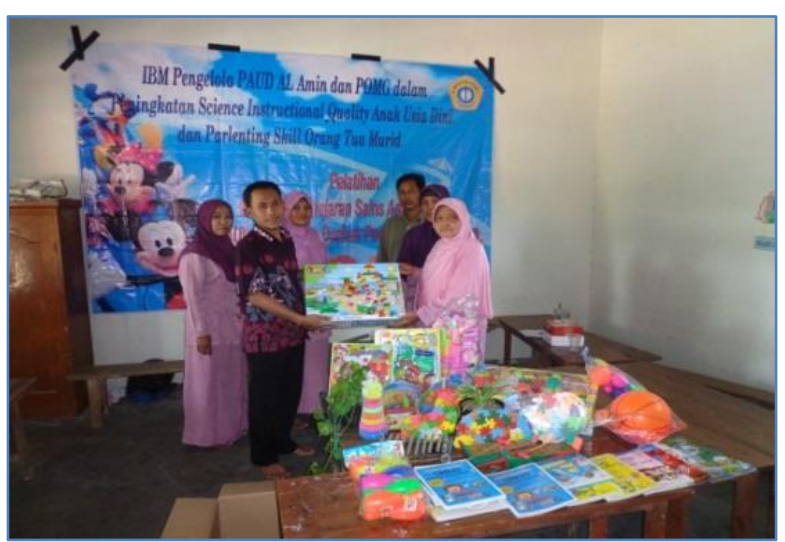

Gambar 4. Penyerahan Media Pembelajaran dan Buku Sains PAUD

\section{KESIMPULAN}

Tujuan utama program IbM ini adalah merubah mindset guru dan orang tua dalam mengasuh anak. Pola asuh merupakan dasar dalam membentuk karakter anak. Midset guru yang kesulitan dalam menyusun RPPH, mengembangkan media juga dapat diubah. Tim IbM berperan sebagai motivator, pemateri, dan juga sebagai pendamping dalam melaksanakan kegiatan IbM ini. Mindset guru dan orang tua sedikit demi sedikit berubah dalam pola asuh anak. Guru juga sudah terampil dalam mengembangkan RPPH hal ini terlihat dari hasil pengembangan yang telah disusun oleh guru melalui proses pendampingan, juga sudah ada peningkatan pemahaman terkait pengembangan media dan memilih media yang sesuai dengan tahapan perkembangan anak.

Dalam program IbM ini masyarakat memberikan respon dengan berpartsisipasi aktif dalam setiap kegiatan yang dilakukan. Beberapa kendala yang teridentifikasi di lapangan adalah minimnya media dalam mengembangkan bahasa, psikomotorik anak. Selain itu, guru-guru juga masih memerlukan beberapa trik untuk mengembangkan daily life skill anak. Guru-guru merasa kesulitan menenmukan format pembelajaran supaya anak bisa lebih mandiri. Beberapa rekomendasi antara tim IbM dengan mitra antara lain: (1) Guru harus aktif memperkaya diri dengan model-model pembelajaran agar tercipta pembelajaran yang baik, (2) Guru harus aktif menerapkan modelmodel pembelajaran yang bervariasi untuk menghindari kebosanan, (3) perlu pengadaan alat peraga dan media pembelajaran yang baik untuk mendukung proses pembelajaran, (4) kegiatan IbM diharapkan dapat terus berlanjut terhadap perbaikan-perbaikan pembelajaran dan kelengkapan media pembelajaran anak usia dini PAUD Al Amin Desa Durbuk Kecamatan Pademawu, Pamekasan, dan (5) pihak mitra berharap adanya kerjasama yang berkesinambungan dalam upaya perbaikan pembe

\section{DAFTAR PUSTAKA}

Biro Pendidikan. 2012. Membantu Anak Anda Di Usia Taman Kanak-kanak. Jakarta: Departemen Logistik Pemerintah.

Duschl, R.A., Schweingruber, H.A \& Shouse, A.W. 2007. Taking Science To School: Learning and Teaching Science in Grades K-8. Washington, DC: The National Academy Press.

George, M. 2012. Dasar-dasar Pendidikan Anak Usia Dini (PAUD). Terjemahan; Fundamentals of Early Chidhood Education, $5^{\text {th }}$ edition. Yogyakarta: Indeks.

Jones, J \& Courtney, R. 2003. Documenting Early Science Learning. National Association for the Education of Young Children. 
Navis, A.A. 2013. Menjadi Orangtua Idaman dengan Hypno Parenting.Yogyakarta: Katahati.

Sharry, J. 2002. Parent Power: Bringing up Responsible Children and Teenagers. England: John Wiley \& Sons, Ltd.
Wiyani, N.A. 2013. Bina Karakter Anak Usia Dini. Yogyakarta: Ar Ruzz Media..

Wiyono, E. 2008. Mengapa Anak Saya Suka Melawan? dan Susah Diatur? Jakarta: Grasindo. 